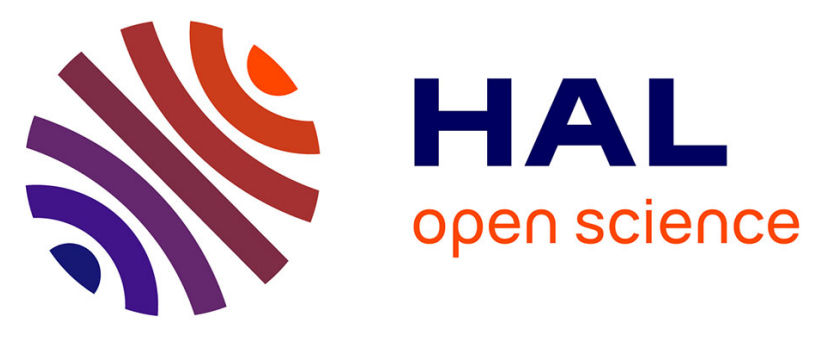

\title{
Sustainable MSD prevention: Management for continuous improvement between prevention and production. Ergonomic intervention in two assembly line companies
}

Sandrine Caroly, Fabien Coutarel, Aurelie Landry, Mary-Cheray Isabelle

\section{To cite this version:}

Sandrine Caroly, Fabien Coutarel, Aurelie Landry, Mary-Cheray Isabelle. Sustainable MSD prevention: Management for continuous improvement between prevention and production. Ergonomic intervention in two assembly line companies. Applied Ergonomics, 2010, 41, pp.591-599. halshs00484609

\section{HAL Id: halshs-00484609 \\ https://shs.hal.science/halshs-00484609}

Submitted on 11 Jun 2013

HAL is a multi-disciplinary open access archive for the deposit and dissemination of scientific research documents, whether they are published or not. The documents may come from teaching and research institutions in France or abroad, or from public or private research centers.
L'archive ouverte pluridisciplinaire HAL, est destinée au dépôt et à la diffusion de documents scientifiques de niveau recherche, publiés ou non, émanant des établissements d'enseignement et de recherche français ou étrangers, des laboratoires publics ou privés. 


\title{
Sustainable MSD prevention: management for continuous improvement between prevention and production. Ergonomic intervention in two assembly line companies.
}

\author{
Caroly, S. ${ }^{\mathrm{a}}$, Coutarel, F. ${ }^{\mathrm{b}}$, Landry, A. $^{\mathrm{b}}$, Mary-Cheray, I. ${ }^{\mathrm{c}}$ \\ ${ }^{a}$ Centre de Recherches en Innovations SocioTechniques et Organisations Industrielles, PACTE- Université Grenoble 2, UPMF, \\ BP 47, 39040 Grenoble cedex 9, France \\ ${ }^{\mathrm{b}}$ Département d'ergonomie, IDC, Université Bordeaux 2, 146 rue Léo Saignat, 33076 Bordeaux cedex, France \\ ${ }^{\mathrm{C}}$ ARACT Centre - 122 bis Faubourg Saint Jean - 45000 Orléans
}

\begin{abstract}
To increase output and meet customers' needs, companies have turned to the development of production management systems: Kaizen, one piece flow, Kanban, etc. The aim of such systems is to accelerate decisions, react to environmental issues and manage various productions. In the main, this type of management system has led to the continuous improvement of production performance. Consequently, such production management systems can have unexpected negative effects on operators' health and safety. Conversely, regulation and control systems focusing on work-related risks have obliged firms to implement health and safety management systems such as OHSAS 18001. The purpose of this type of system, also based on continuous improvement, is to reduce risks, facilitate work-related activities and identify solutions in terms of equipment and tools. However, the prevention actions introduced through health and safety systems often result in other unexpected and unwanted effects on production. This paper shows how companies can improve the way they are run by taking into account both types of management system.
\end{abstract}

Keywords: continuous improvement, OHS management systems, musculoskeletal disorder prevention.

\section{Introduction}

Musculoskeletal disorders (MSD) are today a major concern for companies. The social and economic consequences of this phenomenon have reached such a point that the concern is now being reflected in French public policy.

Scientific reasearch, notably epidemiological, has pinpointed a relationship between MSD and work. The genesis of these pathologies is multi-causal: biomechanical factors caused by workers' movements (frequency, intensity, duration, posture, vibration, cold, etc.), psycho-social factors (stress, decision-making freedom, social support, psychological demand, interest in work, monotony, etc.), and organisational constraints (dependence, contradicting orders, etc.). These risk factors are all mixed together, as described in research in ergonomics and epidemiology. They are the result of workers being exposed to changes to products, production organisation modes, management systems, requirements relating to customer-supplier relations, etc.

Some ergonomists (Bourgeois \& al, 2000, Coutarel, 2004; Douillet \& al., 2005) link MSD with a deficit in terms of how much room for manoeuvre workers have when executing the movements required for their jobs or with respect to the methods used to manage production and human resources. However, this approach has still not been widely developed in international literature or in daily corporate practice. One project, led by several research teams and social partners, called "Sustainable Prevention of MSD and Assessment of the Effectiveness of Actions" (Coutarel \& al., 2006) has identified factors that either help or hinder prevention (Caroly \& al., 2007). One aspect worth focusing on is the way companies deal with MSD through management based on a dual logic of safety and production.

What can be seen is that the prevention of MSD is rarely integrated in company management as information that could have an effect on work performance. Productivity coefficient calculations take into account the forecast operating rates and the actual operating rates of machines, as well as the resources available for production. But the correlation in terms of real people resources is not often made.

Economic research, on the other hand, underlines the importance of taking this latter point into account. Workplace safety as a business objective adds value to the business bottom line. The link between ProductivityQuality-Costs-Safety appears like a sustained approach to competitive advantage. To get optimal benefit from implementing lean manufacturing techniques, companies must include a third variable in their lean manufacturing shibboleth-productivity, quality, and safety. (Maudgalya, Genaidy, Shell, 2008).

The issue relating to the hidden costs of MSD for a company (Fauconnier, Pépin, 2004; Geoffard, 2005) points to the difficulties involved in replacing staff, managing limited skills, absenteeism, workstation adaptation, etc. All of these factors have consequences: failure to reach productivity targets, drops in quality, time wasted recruiting temporary staff, training, etc. Overall production performance is therefore impacted by health and safety issues. Producing such data would therefore greatly 
contribute to decisions relating to change and to the coordination of improvement projects.

Prevention would be more efficient if health were incorporated in the tools and indicators used to run companies. Ergonomics considerations should be an integral part of the planning procedure when establishing new production systems and work places (Westgaard, 2000). Most stakeholders do not realise that there is a link between health and production. Strong management commitment is often a condition for this multiple-logic approach (health, production, maintenance, hygiene, quality, etc.). The need for flexible, rapid and evidence-based preventive approach is underlined to create the possibility of integrating positive, preventive elements into industrial practices (Kuorinka, 1998). Incorporating organisational level into occupational health research seems to be an international question of industry to improve production/safety and preserve worker health (MacDonald, Härenstam, Warren, Punnett, 2008).

The aim of this research paper is to analyse the conditions required for this safety/production logic approach to be integrated in the "continuous improvement" systems of French industry.

\section{Continuous improvement}

Implementing continuous improvement in a company creates an opportunity to link production management with prevention management.

\subsection{Continuous improvement in production management}

In order to increase production, companies use production management systems: Kaizen, one piece flow, automation islands, Kanban, 5S, etc. Such approaches are rolled out in mass production organisations having to face high competition and demanding customer requirements (short lead times, product quality, flexible uses, etc.). The continuous improvement process aims to optimise information, physical flows and products in order to control production costs and quality.

Continuous improvement is based on developing methods, considered to be "original" by managers, where the aim is to have team discussions about the installation of new machines in small spaces; to encourage rapid feedback about operational problems; to facilitate line optimisation using the same resources; to improve responsiveness in relation to customer requests, etc.

With constant raw material and labour price values, optimisation solutions mainly focus on reducing production costs (e.g. number of movements required to assemble a product) by eliminating certain "non-value added" aspects in the production process (processing of useless information, use of ill-suited tools, etc.).

Continuous improvement based on PDCA (plan, do, check and act) cycle logic (Deming, quoted by Kanji, 1996) makes it possible to draw up specifications about the product, to test it in situ and then to re-design it. Improvements are sought by focusing on a so-called normal cycle, but do not take into account product variability and operator fatigue. These production management systems have a limited vision of performance. Indeed, setting up a Kaizen system (e.g. focusing on achieving results while cutting down on resources in terms of time, space andoperators) does not take into account effectiveness, efficiency (Bescos \& al., 1997) and relevance (Hubault, 1998), i.e. the relations between the available resources and the objectives to be reached.

Consequently, the effects of production management on the health and safety of operators are not always included as part of the objectives of continuous improvement. There are only a few exceptions where employee well-being is explicitly said to have a positive influence on the results of a company (Toulouse, 2005). Objectives relating to the development of human resources and management of skills are rarely included in these approaches. These are considered more often as factors that are "external" to these management systems (Du Tertre, 2005).

\subsection{Continuous improvement in safety management}

In terms of regulatory systems for assessing and preventing professional risks, there are safety management approaches (OSHAS 18001, ILO-OSH 2001, etc), based on continuously improving health and safety issues. Furthermore, the traditional OHS specialist's role is increasingly incompatible with the speed of change in today's industry (Kuorinka, 1998).

According to the Deming wheel, the first step when setting up a safety management system consists in drawing up a single document listing all the risks present in a company.

However, this standardised methodology, which is used to produce this type of document, fails to take into account suitable indicators relating to work activities and tends to underestimate the variability of work situations. Risk prevention and management systems should also take into account the diversity of populations,in terms of their age and time spent in the company, as well as their state of health.. Implementing a risk assessment approach should also involve operator participation. Indeed, the solutions available for eliminating risk factors are often thought up by health, safety and environment experts without consulting the workers.

The safety management system tends to underestimate the effects of decisions about production operation. Because such a system focuses on occupational health and safety issues, the objective pursued is to provide workers with greater comfort and adapted workstations. This approach to safety often leads to transformations that actually disturb workers' activities and make strategies focusing on production and quality difficult to implement. This leads to equipment and new procedures being under-used and opposes logic based on safety and that based on production.

\subsection{An innovation challenge: combining production management and prevention management}

Research on innovation shows that the innovation process should combine these different forms of logic. For example, a technological approach should be considered at the same time as a social approach to work. Designing work situations and/or a future work organisation should include the building of compromises, notably between the political wishes of the project owner and the technical feasibility defined by the project manager (Martin, 1998). It should also be mindful of 
the confrontation between heterogeneous forms of logic (Daniellou, 1992), and efficient forms of collaboration between professionals.

In his work on the integration of Occupational Health and Safety in quality management and production management (using Kaizen for example), Georges Toulouse (2003, 2005) confirms that the the conditions for combining these different forms of logic depend on how stakeholders perceive their necessary integration. What factors are likely to convince them of the worth of such an approach? Why is it so difficult to integrate different forms of logic? How can a system for preventing MSD be created and integrated in the way it is run?

The relevance of this meeting between production management logic and safety management logic can be explored through two examples of ergonomic projects where the aim was to set up sustainable prevention of MSD in the company.

\section{Research methodology}

\subsection{Methodological aspects of the general project}

For 3 years, a multidisciplinary group of researchers in ergonomics, sociology and medicine (Universities of Bordeaux and Grenoble, Angers Hospital), together with the National Agency for the Improvement of Working Conditions (ANACT), have been working on a programme, put forward to the French Labour Ministry, to understand sustainable prevention. The general methodology for the project is illustrated in Fig. 1 (Coutarel \& al., 2006)

A study of 30 companies was launched and was entitled "Retrospective study part 1". To perform this study, the project team used a Referential Document about MSD and looked at forms of intervention, company prevention history and direct and indirect performance and health indicators. The team also defined the structure of the case study to facilitate comparisons between descriptive data, MSD prevention, local team intervention, and analyses/hypotheses put forward. Each local team presented their work to an external referee in front of the whole group during meetings.

Some companies (18) requested that the project comprise a second part ("Intervention Part 2") involving the building of a prevention system, a design project and a strategy to improve working conditions. Log books were used to note down any events and describe the changing context and the intervention process. Team interviews were analysed by the sociologists in the research group.

This methodology is based on case studies with emperical and qualitative data. The following and the comparison between some cases can give a support to understand the story of compagnies and the stake of prevention, evolution of workers health and production management, the stakeholders knowledge of MSD, etc. The aim of case study research developed by R.K Yin (1994) is to use a case study protocole with the documentation problem in detail and develop a case study database. The data collection procedures are not routinized. This is because we don't have used a referent group like a quasi-experimental design with a longitudinal approach (Laing, Cole, Theberge, Wells, Kerr, Frazer, 2007).

\subsection{Specific analyses of two companies}

This next section compares two companies, chosen from among the 30 taking part in the project. The way the projects unfolded in these two companies illustrates the issue at hand. Both companies work in similar sectors of activity: the mounting and assembly of parts.

The first company, referred to as "company A", mounts and assembles small parts used in the manufacture of culinary articles. This company had a prevention approach that was not linked to the production management system. The company was followed for a period of 2 years (30 days in the company). The work was performed by a researcher in ergonomics and 2 engineering students.

The other company, referred to as "company B", mounts and assembles water circulation pumps. Unlike company A, this company had a Kaizen production management system. A retrospective analysis of prevention actions was performed in the company. This required a team made up of an ARACT ergonomist and three ergonomics researchers to spend 10 days working there.

The comparison of the two companies involved the following:

- Analysis of documents (social accounting, annual occupational health and safety report, production report, etc.);

- Interviews carried out with several stakeholders;

- Observations of work situations: old assembly line, new assembly line, Kaizen project, etc.;

- Feedback of analysis results given to actors and prevention support provided: steering committee and working group;

- Support with specific actions: structuring of prevention, building of prevention assessment indicators, improvement of working conditions and organisation.

\section{Results of work carried out in assembly companies}

4.1. Company A: Help with the integration of the different forms of logic based on an approach to continuously improve safety

\subsubsection{General context}

In company A, production is organised around a central assembly line distributing products to separate component assembly workstations (Fig. 2). The average cycle time is 24 seconds per operator for clipping, bagging and packaging operations.

The staff is made up of 1,400 technical workers. These operators are mainly female, mostly between the age of 35 and 46, and have worked in the company for many years (18 on average).

With respect to the health indicators, general absenteeism has dropped 19\% since 2002 while absenteeism due to occupational illnesses, industrial accidents and accidents occurring during the trip to and from work continues to increase. The first signs of occupational disease (carpal tunnel syndrome) began to appear in 1995 while the number of sufferers has increased since 2000. The situation is currently critical: a ratio of 0.18 for occupational disease. 
In company A, the concerns of the stakeholders in terms of employee prevention and health are clearly displayed. A prevention unit, reporting to the Managing Director, is in charge of safety and environment issues. An OHSAS 18001 safety management system was recently set up to meet regulatory requirements and the need to improve the organisation and follow-up of actions.

The single document was drawn up between 2002 and 2003 and covered 70 sectors with the help of sector managers and their production engineering officers. The main risks listed were electrocution, electrification and falling objects. The MSD risk did not appear as a risk in its own right (L'allain, 2004). Every 6 months, the document was updated.

However, this risk management method was based mainly on corrective actions, monitoring these and setting up standardisation, rather than on anticipatory actions included as part of design project management. For example, 25 MSD alerts were transmitted to the occupational health and safety committee and recorded in reports between 1993 and 2003. These data show that half of them led to workstation adaptations while the other half led to ergonomic studies that were then filed without leading to any further action.

The so-called safety management system "applied" remains technical and has hardly changed any practices in the long run. It is not linked with other continuous improvement projects in the company.

The prevention unit was seen by all company stakeholders as a source of great suffering for those working in it. Several people took on responsible positions in the unit only to quit them after several years faced with the difficulty of working on safety compared with all the other priorities in the company (profitability, quality, etc.).

\subsubsection{Diagnosis performed}

Following a retrospective analysis of the actions implemented to prevent MSD, the diagnosis showed that the performance of a prevention system depended on how it was linked to innovation projects and changes to the technical process. A working group comprising an ergonomist, the medical unit, the prevention unit, the production engineering team, foreman representatives and staff representatives signed a commitment agreement with the steering committee (site managers, HR managers and industrial manager). The aim of this agreement was to prevent MSD by taking into account all MSD-related factors and looking for a multidimensional solution. This working group gathered all the indicators likely to help understand the phenomenon and drew up specifications about how to set up sustainable MSD prevention.

Using the indicators gathered by the group, an economic analysis of the cost of MSD was performed (Gaillard, 2005). The results were alarming: the cost of MSD for the year 2005 was estimated at over 1 Million euros, i.e. $2 \%$ of the payroll. The ratio of indirect costs versus direct costs was $1: 4$. The main sources of cost for this company came from occupational diseases (direct) and additional wage costs (indirect). This cost approach provided the steering committee with the means of assessing disturbance caused by MSD and allowed it to include this indicator in the existing performance chart.

\subsection{4-Actions performed}

The observations made by the working group on two production lines underlined the need to develop an ergonomic design approach covering concerns about worker movements and difficulties assembling products with packaging. The working group took the opportunity of a project to improve the two lines in order to put forward health and safety recommendations.

It appeared necessary to develop ergonomic integration for the industrialisation of new products, with a focus on finish operations, which tended to be forgotten. The steering committee validated this proposal for action by moving the medical unit's ergonomist to the production engineering \& industrialisation department in the organisation chart.

Thus, the working group interviewed different stakeholders in order to understand their difficulties. It was found that a gap of 5 millimetres in diameter between the utensil and packing box required workers to exert considerable pressure in order to insert the utensil into the box. This problem was mainly due to a "lego" effect. Each packed utensil did not have a specific reference but several simultaneous references: seal, plastic film and decoration. The fit between the packaging and the utensil was only checked at the launch of the new range. No prototype was used, which sometimes meant over 10,000 articles having to be squashed into packaging that was too tight. Today, ergonomic criteria have been added to the packaging specifications and tests are performed before a product is launched.

Furthermore, the working group set itself an objective to think about how to continuously improve production management. The production management system was based on manufacturing releases that scheduled production work on the lines according to the upstream process references. These references were linked to a broad variety of ranges, components and materials. The work orders were then sent on to the team leaders in charge of organising their sector. Because work orders were launched without knowing what the manufacturing requirements were, team leaders sometimes had to deal with contradictions in the production system. In spite of these problems, the company had not set up a continuous improvement system: no FMECA, no analysis of production incidents and no appropriation of the 5S method. In 1997, an external company had set up another working group to work on the Kaizen approach: identification of "non-value added" stages and search for solutions, validated by managers. But this approach was massively rejected by the personnel and the occupational health and safety committee because work organisation was designed with shorter cycle times, workstations were not taken into account, there was no focus on operator movements or inter-dependency.

The aim of our approach was to reinstate a continuous improvement procedure for production, notably when it came to following up unexpected events. These were seen to be costly in terms of MSD. Failure to take them into account basically amounted to failing to recognise the workers' real difficulties. 
The analysis of the actual situation in the field led to concrete actions being taken. For example, the number of components to be mounted on a culinary article could vary from 1 to 8 . One of the unexpected problems studied was caused by a drop of aluminium at the injection point creating greater pressure on workers' hands when clipping the bakelite into position. For different reasons, it took over 6 months to follow up this problem and change the production process. An in-depth discussion took place with the steering committee about how to structure the system for following up such problems and set up a precise procedure for requesting and carrying out modifications.

\subsection{5 - Future perspectives}

The team's involvement helped to progressively integrate production indicators in the safety management system. However, the absence of the marketing department sheds uncertainty on proposed improvements. For example, in the space of a few years, the weight of utensils has increased by several grammes. This equates to an additional handling weight of $5.7 \mathrm{~kg}$ a day.

In fact, the product marketing policy is based on the idea that the weight of an object suggests that it is robust and made from quality materials. This means that lighter products cannot be designed, but does not mean that there cannot be any discussions about how to facilitate product mounting and assembly.

Progress also needs to be made in order to integrate quality-based logic with the other forms of logic. For example, a prototype designed by the production engineering manager, the physiotherapist and the occupational risk specialist was tested on the packaging workstations. It had two biomechanical objectives: to prevent articles from having to be lifted and to cut down on strenuous upper arm movements.

When the prototype was tested for the first time, the objective was called into question as the operator had to look at the handle of the pan and put her hand inside the utensil to check the quality of the weld. As the activity had not been analysed beforehand, all of the requirements in terms of equipment design had not been taken into account.

Furthermore, there are still issues relating to the compromise between management of human resources and management of risks. Company A currently manages people with limited skills by assigning them to adapted workstations on a specific line producing simple products. Faced with the increase in MSD and the ageing population, collective actions should be implemented such as a rotation system.

If each stakeholder took into account the different forms of logic, this would encourage health indicators to be included in the design of technical processes and work organisation conditions.

\subsection{Company B: Difficulty setting up compromises between different forms of logic using a continuous improvement approach in production}

\subsubsection{General context}

In company $\mathrm{B}$, the water circulation pumps for boilers are assembled in automation islands, moving from one workstation to the next (Fig. 3).

The production rates are high (average cycle time of 22 seconds).

This company employs 256 people in production. They are mostly women aged between 35 and 55 years of age having worked in the company for a long time (over 16 years).

In terms of health indicators, worker absenteeism has been going up every year. Industrial accidents represented 212 days of leave in 2004: $49 \%$ requiring hand care, $11 \%$ arm care and $11 \%$ treatment of the lower limbs. Few MSD incidents are actually declared. The workers undergo operations for carpal tunnel syndrome without filling in a declaration.

\subsubsection{Prevention structuring}

The company began to be interested in the question of MSD in 1999. At that time, the Kaizen approach, promoted by the new site manager, had just been introduced. Neither the safety manager nor the committee on occupational health and safety played a role in its deployment although the committee, including the HR manager, still dealt with health issues.

The integration of the company nurse followed by the handing in of her notice is symptomatic of the company's ambivalence when dealing with health and safety questions. The company wanted to include health and safety logic in its change process but was unable to do so owing to the power struggles between different stakeholders. The concrete problems encountered by the workers were rarely discussed and required further field investigations.

\subsubsection{Diagnosis performed}

In company $\mathrm{B}$, the focus is more on managing the production management system than on health and safety. The Kaizen projects occupy a very important position in the life of the company:

- One person is specifically in charge of the approach (Kaizen manager);

- Workstations are constantly being reorganised;

- A system allowing people to suggest improvements has been set up and entails financial rewards for workers who find solutions to problems encountered on the job.

The company has several simultaneous approaches in order to continuously improve the production system. However, there is no real consistency between the different projects. Thus, improvements, notably technical ones, are not applied everywhere: effective actions performed in one automation island are not necessarily carried over into another island (e.g. balanced and light screwdriver standards), causing a loss of know-how and wasted time and a low level of innovation transfer.

Health-related changes focus on standardisation. This was the case of workstations considered to be too low, and out of line with comfort-related standards, when the diagnosis was performed in 1999. When the Kaizen approach was 
implemented, workstation heights were moved up closer to ergonomic standards. Management and supervisory staff determined the goals to be reached before the Kaizen approach was launched. These were to guide the project but did not involve health issues.

\subsubsection{The Kaizen projects}

Although the Kaizen projects offered operators the opportunity to express their difficulties, many of these were not actually dealt with as part of the projects. This can be illustrated through two examples: space-saving on the ground and greater added value.

One project observed explicitly aimed to reduce working surfaces by $30 \%$. This had the following consequences:

- The operators were no longer able to get a trolley carrying some fairly heavy tools into the work island. These tools had to be changed with each series modification. The changeover was timed making things even more difficult.

- Product packaging was individual for some customers (small box instead of a pallet), but there was no area available to perform this packaging operation. Workers had to adopt strenuous postures and work at unsuitable heights. The" mistake » of ergonomics intervention, that concern the link between ergonomics and rationalization measures contributed to the frequent failure of the attempts of MSD improvement by the introduction of " best practices" (Winkel, Westgaard, 2008).

The lack of assessment of the situations generated did not really call the Kaizen project into question. Although the Kaizen philosophy includes health and safety aspects, the way the projects were carried out revealed something quite different.

In the space of 6 years, the size of the production areas was reduced by $52 \%$ on average for each island (Table 1). Only the surface areas used for automatic machining were not altered. By reducing automation island space other islands could be created in order to meet increasing customer demand. Between 1999 and 2006, the number of operators working in an island went down from 6 to 5 (Fig. 4). The first workstation in the line used for preparation, which occupied a central position, was moved to an "in-island" position. This first workstation enabled the operator to see progress on the last workstation and anticipate preparation work. With the new position, the operators worked with their backs to each other, making any collaboration difficult. They had to frequently rotate their torso for the work to be carried out. Two other negative consequences were observed: the operators no longer had any intermediate storage spaces and the workstation area available meant that training in teams of two was no longer possible.

Workstation organisation was also revised with the aim of increasing added value. In 1999, a loader picked up the finished product in the island by shuttle. In 2006, one operator out of the 5 working in an island was put in charge of loading/collecting the finished product. The other operators had less time for breaks because they had more work to do.

In 1999, operators organised which workstations they worked on themselves (changing between different stations), except for the last workstation. In 2006, they no longer changed stations, hence reducing the possibility for collective work in the island: less collective management of orders, deteriorated atmosphere, mutual aid less possible, with each operator using their resources to the full.

In the end, this overall decrease in work spaces together with the organisational changes contributed to increasing MSD-related risks (biomechnical constraints). These examples of the Kaizen approach underline the divide between the philosophy and the reality of the actions carried out. Health was not considered to be as important as quality or production.

\subsubsection{Suggested improvements ${ }^{1}$}

Difficulties are expressed in the form of "Suggested Improvements". When faced with a problem on the job, workers are invited to put forward a solution. The suggested improvements are then studied, accepted and put into practice.

An analysis of the way the suggested improvements system worked reveals a number of limits:

- The improvements selected and rewarded by management were those that helped to decrease the number of "unnecessary body movements" and displacement. Ideal suggestions were those that entailed little cost and could be quickly implemented.

- The chosen solutions often contributed to setting up work that required a static posture.

- The way the improvements worked depended on two types of skills: identification of a workrelated problem and invention of a solution by the operator. However, the solutions were not always easy to identify and required knowledge of the production system.

This suggested improvements system came up against numerous difficulties, which made worker participation illusory and ineffective. Some operators admitted that they had not put forward any suggestions for months.

Thus, the changes generated by the Kaizen project and the suggested improvements were subordinate to the company's goal to achieve higher productivity. But the solutions were prepared without taking into account logic relating to health and safety.

\subsubsection{The actions performed}

When the company was given feedback about integrating health and safety logic in its change process, this was not taken on board by the actors. The industrial manager left several weeks after the feedback was given, thus holding up the rest of the approach.

Yet, the suggested improvements in terms of MSD prevention explored several possibilities:

- production of data based on an MSD questionnaire in order to gather health indicators;

- action training by the immediate supervisory staff and management, decided on by the occupational health and safety committee. This training was to focus on ergonomic

\footnotetext{
${ }^{1}$ In company B, the suggested improvements system was separate from the Kaizen project in terms of the way the suggestions were dealt with and solved.
} 
work analysis methods and a joint model for understanding human factors at work and MSD factors.

These suggestions were in line with a buy-in to an integrated approach to prevention in continuous improvement procedures by the company's internal stakeholders. But the new industrial manager did not consider the MSD risk as a priority.

\subsubsection{Future perspectives}

Two hypotheses can explain the difficulties underlying prevention dynamics in the company: the temporality of the management processes and the positioning of certain stakeholders.

The disjunction between prevention-based logic and production-based logic can be initially explained through the search for solutions that could be quickly and easily implemented at little cost. This management method is above all controlled by the goal of higher productivity. Activities of engineers and ergonomists when attempting to manipulate time aspects of work may be contradictory; engineers wishing to improve time-efficient production and ergonomists assessing time aspects of work aiming at better health as well as contributing to production (Wells, Mathiassen, Medbo, \& Winkel, 2007). Integrating health and safety logic in the change process, on the other hand, would have required complex and time-consuming solutions. This supposes different control conditions and a change in positioning with respect to the highly time-conscious production management (just-in-time, no WIP, no stock, etc.). But nothing would seem to impose the temporality of production on the continuous improvement process. It seems to be more efficient to analyse time and ergonomic aspects in early design phases of work process (Sundin et al., 2004).

The calling into question of the production management system would seem to depend on the different management teams' acceptance of this. The position of the safety manager with respect to the other stakeholders in the company is another substantial limit.

\section{Discussion:}

\subsection{Disjunction between forms of logic}

In both companies, it can first of all be seen that the continuous improvement programme, implemented before the intervention work, focused on the production system or the safety management system. Any sort of compromise between performance-based logic and health-based logic was absent. There were obviously problems, and the diagnosis had led to solutions being sought, but according to a single logic, i.e. the one identified at the beginning. The assessment of improvement actions was not very well carried out, not very participative and did not lead to the building of indicators to facilitate the way different forms of logic were managed in the company.

The appearance of MSD differed according to the company. In terms of health indicators, there were two opposing trends: in one company there was low absenteeism but a high level of occupational illnesses, while in the other company it was the other way round. These health indicators could be used to mobilise managers around a prevention policy for company A.
The building of a consistent management approach is nevertheless hindered by the daily problems involved in carrying out the actual work:

- when they start their shift, the team leaders manage absenteeism as best they can,

- production is slowed down by machine breakdowns and other unexpected problems,

- in spite of the accident analysis, there are still many situations involving risks,

- quality goes by the wayside when decisions are taken upstream before any understanding of the reality downstream is sought,

- there is an increasing gap between work organisation flexibility (in order to meet customer requirements) and the rigid production methods (dependence between colleagues).

This divide between different forms of logic prevents the company from analysing operational problems and using effective actions in project management. Does the production system give operators any room for manoeuvre so as to foster a compromise between health and performance? Is there a system for coordinating a production-based approach and an apporoach focusing on health? Who are the stakeholders involved in production organisation and those involved in risk prevention? What kind of social dialogue does the company have?

\subsection{Conditions for integrating prevention in the production system}

The comparison between these two companies has opened a discussion about the conditions for building prevention actions that can be integrated in a company's production logic. This discussion has led to several exchanges within our team of ergonomists and engineers (Caroly \& al., 2006). Our work aimed to guide the process of integrating prevention according to the set-up of the production management system.

In company A, the MSD risk identified at the start as a specific risk by the people in charge of the safety management system was entirely sub-contracted out to the health unit. This risk did not benefit from the continuous improvement process, leading to insufficient follow-up and non-fulfilment of actions. Our work led to the MSD risk being taken into account as an overall, multiple-factor risk, querying equipment design, the types of strenuous movements performed, organisational problems, etc. This approach facilitates the transformations required and helps to integrate the different forms of logic.

In company $\mathrm{B}$, management is based on production indicators. The suggested improvements system and the Kaizen projects do not take into account safety logic. The question here is how to put health and safety questions on the agenda when the stakeholders believe that everything is going well given that the production indicators are good? Introducing prevention logic to an already well-defined management system requires helping the stakeholders to draw links between quality and safety, to become aware of the professional risks arising from improvements (e.g. revising the layout of work spaces). Many quality defects may be due to tasks being badly designed (Jörgen \& al., 1995). Understanding the negative influence on the quality of production may be an opportunity both to improve quality and eliminate WMSDs. (Kuorinka, 1998). Marketing 
requirements should be discussed in relation to equipment design and workstation layout. The existence of a positive relationship between the ergonomic design of workplaces and achieved product quality levels is not easily established due to the difficulty involved in changing production procedures in a real workshop exclusively (Gonzales, Adenso-Diaz, Gonzales Torre, 2003).

\subsection{Assessment: a tool for integrating different forms of logic}

Assessing the unexpected effects of some transformations appears to be essential when helping companies to set up sustainable prevention that includes health and safety issues. It is a question of not excluding one model for the benefit of another, but rather of searching for a compromise between possible work approaches. The building of a debate between stakeholders about these different forms of logic makes it possible not only to take into account other stakeholders' requirements but also to find a new form of consistency, which would not have been possible without any discussion. To this end, our work focused on building indicators for assessing improvement projects, on the one hand, and pooling knowledge about operational problems in order to develop actions allowing more room for maneouvre, on the other hand (Fig. 5).

The meeting between quality, ergonomics, productivity and safety depends on a policy based on integration and compromise between different forms of logic in the company. It depends on the involvement of all stakeholders (management, occupational health and safety committee, human resources manager, operators, etc.), and on a collective approach that encourages actions to be assessed and operational problems to be dealt with.

\subsection{Conditions for mobilising continuous improvement project stakeholders}

The actors likely to suggest improvements may be many and varied. The ergonomist, focused on the work to be carried out, will attempt to explain why solutions fail. The engineer is more concentrated on results while at the same time concerned about meeting regulatory requirements in terms of safety and production efficiency. Improvement objectives are pursued with reference to the engineers' technical expertise. The ergonomist should also look into the activity of "intermediary design stakeholders" (technicians, production engineering, quality, etc.), involved in the Kaizen projects.

The participatory ergonomics approach used resulted in redesigns of the new product. Interesting results have been described by such interventions: improvement of efficiency and ergonomics of the assembly operations (Sundin, Christmansson, Larsson, 2004 of greater comfort and higher productivity (Vink, P., Koningsveld A.P., Molenbroek, J.F., 2006).

The continuous improvement approach recommends that all actors participate, without this philosophy actually querying the limits of such participation. Some workers' problems cannot be immediately solved, either because the designers do not have any room for maneouvre in terms of what they can do (notably with respect to time available, work load, position), or because their expertise is destabilised by the contradictory demands of workers. This is not only a problem of training and willingness on behalf of the designers, who say they are interested in including health and safety in their production tool transformations (Toulouse, 2005). It is a question of how to create the necessary room for manoeuvre for these engineers. The sustainable prevention of workers health should take into account : management responsibility, worker responsibility, systems for rapid feedback, system flexibility and cost effectiveness, clear roles of stakeholder and use of an ergonomist in an advisory expert role (Weestgaard, 2000).

Furthermore, the possibility of integrating health and safety in a company's projects can be developed thanks to a work collective made up of multiple-logic stakeholders (production engineer, ergonomist, professional risk specialist, foreman, company nurse, etc.). Room for maneouvre depends on how this work collective functions and, in return, offers the possibility of building other areas where room for maneouvre is possible for activities that are specific to each stakeholder according to their position in the company. Encouraging the actors to promote the integration of different forms of logic allows each one to assume their professional role in the negotiation and set up compromises with the others. In reality, it involves providing the means for a sustainable improvement project where the stakeholders involved in prevention and those involved in production can express their needs so that actions are effective: for example, refusal to take on temporary workers on some production lines, type of subcontracting for activities, form of customer requirements, reasonable lead times, employment of young people, and retirement of senior workers, etc.

The possibilities for building compromises between health and production depend on how disposed stakeholders are to taking these different forms of logic into account, on their ability to call into question the type of solution to be set up following a suitable diagnosis of the work situation, and on the participative project experience (Toulouse, 2005).

Setting up sustainable MSD prevention should involve training engineers and social stakeholders but also drawing up recommendations about production organisation that take into account safety issues. Furthermore, the dynamics behind public policy could also support these actions and initiatives inside companies. Company governance depends on "capability" (Falzon, 2005) in terms of fostering thinking about performance, where the human factor is considered in technical changes and work organisation methods (Erlicher \& al., 2005; Törnström \& al., 2008). Knowledge management is one possible strategy for reaching the objective to develop prevention management systems (Sherehiy \& al., 2006), but this approach does not seem to go far enough when it comes to promoting the organisation of work based on the integration of different forms of logic. Best practices are still too often based on a standardisation model providing little opening for debates about continuous improvement actions and project management. On the contrary, discussions must allow for the diversity and heterogeneity of the production process in order to develop resources for workers and their supervisory staff. In this respect, performance assessment focuses more on innovation processes resulting from the controversy between actors rather than simple knowledge about work processes. 


\section{References}

Bescos, P.L., Dopler, P., Mendoza, C., Naulleau, G, Gireai, F., Lerville, A., 1997. Contrôle de gestion et management. Oaris : Editions Montchrestein, $4^{\text {ème }}$ édition.

Bourgeois, F., Lemarchand, C., Hubault, F., Brun, C., Polin, A., Faucheux J.M., 2000. Troubles musculosquelettiques et travail. Quand la santé interroge l'organisation. Editions ANACT, collection outils et méthodes.

Caroly, S., Coutarel, F., Daniellou, F., Landry, A., Escriva E, Roquelaure, Y., 2007. Assessment of the interventions on sustainable prevention of musculoskeletal disorders: comparison of twenty companies. Book of Abstracts of Premus 2007, Congress 27-30 august 2007, Boston, Massachusetts, USA, 332

Caroly, S., L'Allain, C., Landry, A., 2006. What is the relation between production management systems and management strategies about working risks? Continuous improvement is under discussion of Engineering and Ergonomics domains. Proceedings of the IEA 2006, Congress 10-14 july, Maastricht The Netherlands.

Coutarel F., 2004. La prévention des troubles musculosquelettiques en conception: quelles marges de manœuvres pour le déploiement de l'activité ? Thèse, Université Bordeaux 2, LESC, France.

Coutarel, F., Daniellou, F., Dugué, B., Landry, A., Caroly, S., Cholez, C., Roquelaure, Y., Douillet, P., 2006. Substainable prévention of musculosketeal disorders: methodological aspects of a projet on assment of the efficiency of interventions. Proceedings of The IEA Congress 2006, 10-14 july, Maastricht The Netherlands.

Daniellou, F., 1992. Le statut de la pratique et des connaissances dans l'inervention ergonomique de conception. Thèse d'habilitation. Université de Toulouse.

Douillet P, Schweitzer JM., 2005. Les conditions d'une prévention durable des TMS. Editions ANACT, Etudes et document, Lyon, 6-12.

Du Tertre, C., 2005. Services immatériels et relationnels : intensité du travail et santé. Activités. Vol $2, \mathrm{n}^{\circ} 1$.

Erlicher, L, Massone, L., 2005. Human factors in Manufacturing: New Patterns of Cooperation for Company Governance and the Management of Change. Human Factors and Ergonomics in Manufacturing 15 (4), 403-419.

Falzon, P., 2005. Ergonomics, knowledge development and the design of enabling environments. HWWE - Humanizing Work and Work Environments, 10-12 december 2005, Guwahati, India.

Fauconnier, D., Pépin, M., 2004. L'approche économique des TMS. Rapport ANACT-ESSOR et ITG Consultants, Paris.

Geoffard, P.Y., 2005. Théorie économique et prévention des risques professionnels. In colloque DARES-ANACT 2 décembre 2005, Paris

Gonzalez, B.A., Adenso-Diaz, B., Gonzalez Torre, P. 2003, Ergonomic performance and quality relationship: an empirical evidence case. International Journal of Industrial Ergonomics 31, 33-40Hubault, F., 1998. Articulations rigides pour coordinations souples? Les TMS comme syndrome de crise du modèle taylorien de régulation. In: Bourgeois, F. (éd). TMS et évolution des conditions de travail, actes du séminaire Paris $1998,47-53$

Jörgen, A., Eklund, E., 1995. Relationships between ergonomics and quality in assembly work. Applied Ergonomics 26 (1), 1520.

Kanji, G.K., 1996. Implementation and pitfalls of total quality management Total Quality Management \& Business Excellence 7 (3) $331-343$

Kuorinka, I., 1998. The influence of industrial trends on workrelated musculoskeletal disorders (WMSDs). International Journal of Industrial Ergonomics 21, 5-9.Laing, A.C., Cole, D.C., Theberge, N., Wells, R.P., Kerr, M.S., Frazer, M.B., 2007. Effectiveness of a participatory ergonomics intervention in improving communication and psychosocial exposures. Ergonomics 50 ( 7), 1092-1109.
MacDonald, L.A., Härenstam, A., Warren, N.D., Punnett, L., 2008. Incorporatink work organization into occupational health research: an invitation for dialogue. Occup Environ Me. 65 (1), $1-3$.

Martin, C., 1998. La conception architecturale entre volonté politique et daisabilité technique : le positionnement de l'intervention ergonomique. Thèse de doctorat d'ergonomie. Paris. CNAM.

Maudgalya, T., Genaidy, A., Shell, R., 2008. Productivity-QualityCosts-Safety: A Sustained Approach to Competitive Advantage-A Systematic Review of the National Safety Council's Case Studies in Safety and Productivity. Human Factors and Ergonomics in Manufacturing 18 (2), 152-179.

Sundin, A., Christmansson, M., Larsson, M., 2004. A different perspective in participatory ergonomics in product development improves assembly work in the automotive industry. International Journal of Industrial Ergonomics 33, 1-14.

Sherehiy, B., Karwowski, W., 2006. Knowledge Management for Occupational Safety, Health, and Ergonomics. Human Factors and Ergonomics in Manufacturing 16 (3), 309-319.

Törnström, L., Amprazis, J., Chritstmansson, M., Eklund, J., 2008. A corporate workplace model for ergonomic assessments and improvements. Applied Ergonomics 39 (2), 219-228.

Torp, S., Moen, B.E., 2006. The effects of occupational health and safety management on work environment and health: A prospective study. Applied ergonomics 37, (6), 775-783.

Toulouse G., 2003. Intégration de la prévention SST au management des normes ISO 9000 par la macroergonomie : une recension des écrits suivie d'un projet pilote. Rapport IRSST, R-324.

Toulouse, G., Nastasia, I., Imbeau, D., 2005. Etude de faisabilité en vue d'intégrer la SST à l'approche PVA-Kaizen. Rapport IRRSST, R-428.

Vink, P., Koningsveld A.P., Molenbroek, J.F., 2006. Positive outcomes of participatory ergonomics in terms of greater comfort and higher productivity. Applied ergonomics 37 (4), 537-546.

Weestgaard, R.H., 2000. Work-related musculoskeletal complaints: some ergonomics challenges upon the start of a new century. Applied ergonomics 31, 569-580.

Wells, R., Mathiassen, S.E.Medbo, L., Winkel, J., 2007. Time - a key issue for musculoskeletal health and manufacturing. Applied Ergonomics 38 (6), 733-744.

Winkel, J., Westgaard, R.H., 2008. Facteurs de risques de TMS au travail et perspectives de solutions : passé, présent, avenir. HESA Newsletter 34, Juin 2008, 3-7.

Yin, R.K., 1994. Case study research. Design and methods. Second Edition, Applied social research methods series 5; Sage Publication. 